\title{
IMPROVE THE PRODUCTIVITY OF BROILERS USING AN EVAPORATIVE COOLING SYSTEM
}

\author{
Ibrahim, M.H.***, Abdel Ghaffar, E. A.***, \\ Hassan, M. F.** and Bayomy A., M.*
}

\begin{abstract}
This research was carried out to investigate the feasibility of using an evaporative cooling system to improve the productivity of broilers. Two different treatments cool and control rooms were used in the experiments. Mathematical computer program was first developed and the output results were used for designing the evaporative cooler. The system was manufactured and installed in the cool room for field tests. A comparison was carried out, afterwards, between birds grown in the two rooms for the bird performance, feed conversion ratio, and mortality rates. A cost analysis proved that the profits were 2723 and 1820 EG.P./life cycle for the cool and control rooms, respectively. The profit of birds produced in the cool room was almost 1.45 times that of birds produced in the control room. Therefore, the evaporative cooler was successfully increased the profit and appeared economically feasible to use.
\end{abstract}

\section{INTRODUCTION}

The poultry industry in Egypt is considered one of the most important enterprises which produce more meat protein for the food Egyptian unit weight than other meat industries. Commercial poultry farms for meat production are quite often wide spread across the country. The broiler production in Egypt has grown from 278 thousand ton per year in the early 1990's to 643 thousand ton per year in 2002, (FOA, 2002).

Heat stress caused by high summer temperature reduces production, depresses growth rates, and increases mortality (Howes et al., 1962., Deaton et al., 1978., Harrison and Biellier, 1969). Weight gain declines because the birds stop eating to focus attention on temperature control.

\footnotetext{
${ }_{* * *}^{*}$ Prof. Agric. and Bio-systems Eng. Dept., Fac. of Agric. (Chatby), Alex. Univ., Alex.

*** Prof. of Poultry production. Dept., Fac. of Agric. (Chatby), Alex. Univ., Alex.

*Eng. - M. Sc. Agric. and Bio-systems Eng. Dept., Fac. of Agric. (Chatby), Alex. Univ., Alex.
} 
The situation is most serious when birds are approaching their market age because of the maximum rate of sensible heat produced by birds. While on the other hand the required inside air temperature must be kept at the minimum level of $21{ }^{\circ} \mathrm{C}$, (Ibrahim, 1988). Significant losses from heat stress - related deaths can be expected to occur whenever broilers are exposed to temperature greater than $35^{\circ} \mathrm{C}$ for extended periods during the last two weeks of grow-out (MWPS, 1983). Exhaustion sets in quickly and mortality frequently is the result.

In Egypt, several investigations dealt with the required ventilation rate and energy demands for broiler houses (Abdel-Ghaffar, 1984; Hatem, 1987 ; Ibrahim, 1990; and Abouzaher, 1998). Other studies suggested some systems to achieve better ventilation and energy requirements, (Hatem, 1988 and Ibrahim, 1993).

Thus, this research was conducted to evaluate the performance of using an evaporative cooling system for increasing broiler production. A computer program was firstly developed to describe the performance of broilers, simulate the optimum environment, and calculate the cooling loads required during the summer months. Cooling loads for the summer season and ventilation rates required to control air moisture, air temperature, and ammonia were computed and the maximum one was used for sizing the pad of the evaporative cooler.

The fan-pad system used by the evaporative cooler was manufactured and installed thereafter, based upon the computer simulation output, for the field tests. Two broiler rooms were used. One room was equipped with the evaporative cooler, while the other was used as a control treatment. Mechanical ventilation was employed with the evaporative cooler, while natural ventilation was used in the control room to relief the heat stress imposed on broilers. A comparison was carried out, afterwards, between birds grown in the two rooms for the bird performance, feed conversion ratio, and mortality rates. 


\section{MATERIALS AND METHODS}

\section{Field testing the evaporative cooling system}

\subsection{Facility description}

The field experiments were carried out in a poultry building in the Agricultural Experiments and Research Station, Farm of Faculty of Agriculture, Alexandria University. The experiments were conducted during the period from August to September. The poultry building which was used to raise the broilers during the growth out period, has $78 \mathrm{~m}^{2}$ net floor area.. It was divided into two identical rooms when birds reached the age of 21 day. Each room was almost $6 \times 6 \mathrm{~m}^{2}$ floor area. One room was equipped with the evaporative cooling system as a treatment, while the other room used only the natural ventilation, (the control treatment). New litter was placed in each room before starting the first stage of experiments. Clean straw and dry wood shavings were used as a floor litter of $10 \mathrm{~cm}$ depth on a thin layer of limestone before receiving chicks.

The heating system was ignited 24 hours before chicks arrival to preheat the house, water, and floor litter. It was also employed to provide a warm and comfortable environment for the chicks. Electrical brooder heaters were used for warming the environment particularly at night. Cardboard brooder guards of $35 \mathrm{~cm}$ high were used at the beginning of the experiments to keep chicks close to feed and water. The food troughs were half filled in order to reduce feed waste.

The chicks used in this study were belonging to a commercial broiler hybrid called Hubbard. A total number of three hundred forty five unsexed day old Hubbard broiler chicks, Arbo Eaker type, were bought in July, 2005. On the arrival day, the chicks were wing banded for identification, individually weighted and vaccinated for Newcastle disease. The chicks were reared in litter - open floor house until the age of 21 days with eight bird/meter square stocking density.

The birds were left on an open floor for adjusting and tempering conditions. When birds reached 21 days, the building was partitioned into two rooms. The birds were divided thereafter into two groups. Each group was placed in one of the two growth rooms. Birds were settled and the experiment was conducted until the age of 45 day, the market age. This 
was carried out since the last two weeks of broiler production were the most critical period of production in summer seasons.

Each growth room was also partitioned into nine sections during the growth out period. This was carried out for the purpose of statistical analysis. Three different stocking densities 8,10 , and $12 \mathrm{bird} / \mathrm{m}^{2}$ were used in each room with three replicates for each stocking density.

A layout of the two blocks, ventilation systems, and the stocking densities with their replicates are shown in Figure (1).

All chicks at the beginning of the experiments received a commercial mash ration and libitum with free access to water until the end of the experiment. This ration contained $21 \%$ crude protein, $3 \%$ crude fat and crude fibers less than $3.2 \%$.

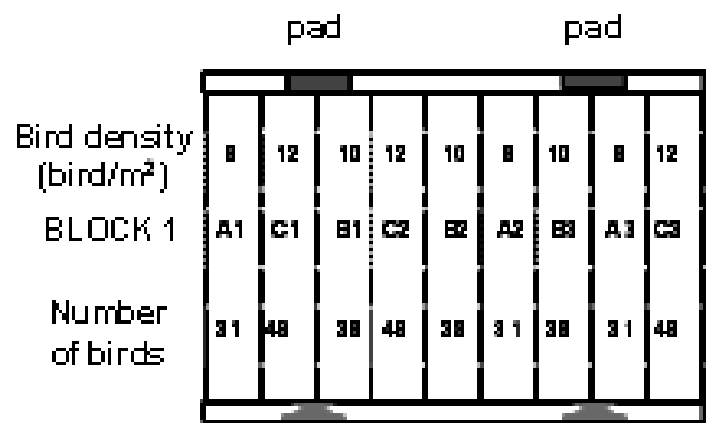

Fan

Fan

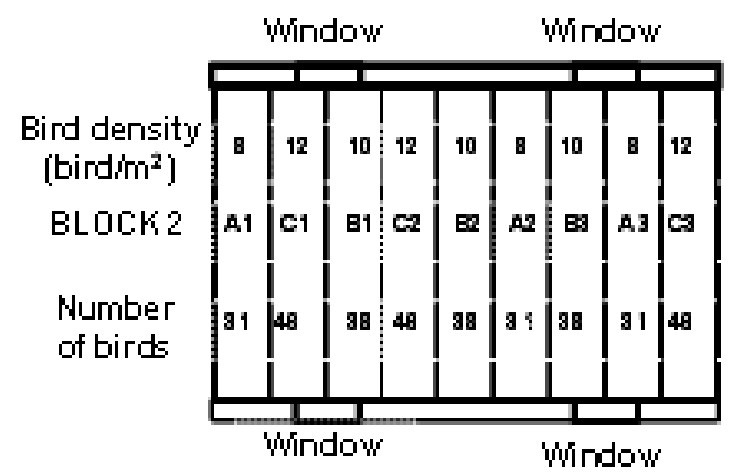

Fig. (1). A schematic diagram of the experimental design.

(A,B and C: Treatments, 1,2 and 3 : Replicates)

It was produced by $\mathrm{El}$ - Kahera feed company. The ingredients were yellow corn, Soybean meal $48 \%$, Corn gluten $60 \%$, Poultry by-products, meat meal, sunflower meal, salt, limestone, vitamins premix, lysine and methionine.

\subsection{Sizing the evaporative cooling system}

In order to achieve a high cooling performance, pad material and thickness, air velocity and water flow in pads are such factors that were taken into consideration. For agricultural applications, pads are normally mounted vertically in one side wall of the building, while the fans are installed on the opposite wall. 
Porous materials generally provide the most efficient cooling operation. A porous material (Srand) was used as the pad material in manufacturing the evaporative cooler, Figure (2). Pad thickness was another important factor that was taken into account in the evaporative cooler design. A pad thickness of $12 \mathrm{~cm}$ was used for the cooler. A range of $10-15 \mathrm{~cm}$ for pad thickness is commonly used in commercial agricultural applications as shown in Figure (2).

Most literature recommended $1.25(\mathrm{~m} / \mathrm{s})$ as a practical and efficient pad face air velocity for evaporative coolers with aspen pads, (Wiersma and Benham, 1974). They found that the maximum efficiency of an evaporative cooling system was obtained at air velocities of $1.25(\mathrm{~m} / \mathrm{s})$ in vertical pads and nearly $1.5(\mathrm{~m} / \mathrm{s})$ in horizontal pads. However, they recommended a pad face air velocity of $1.25(\mathrm{~m} / \mathrm{s})$ because of the increase of pressure drops at high air velocities. Air velocities greater than 1.5 $(\mathrm{m} / \mathrm{s})$ also tend to pull free water into the air stream.

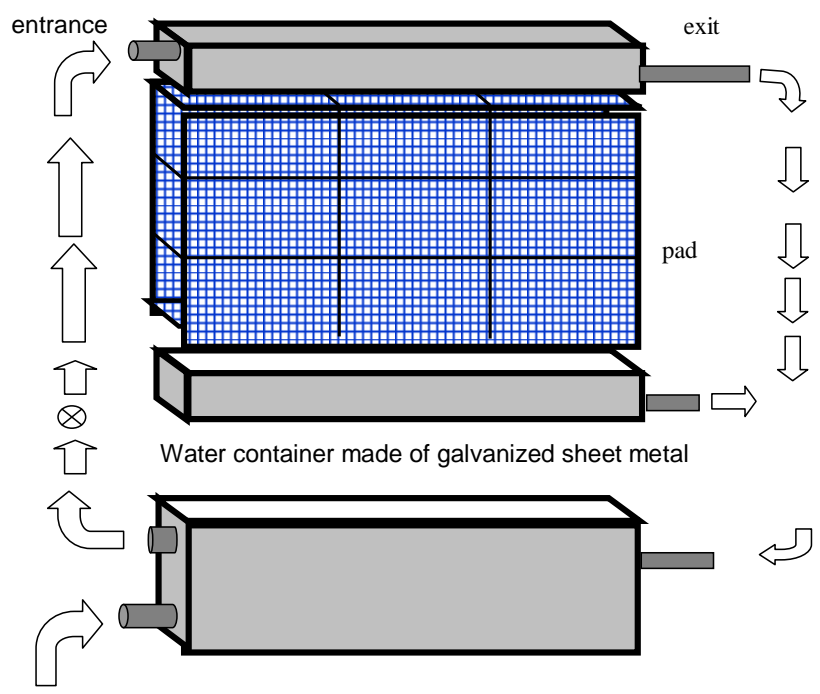

Fig.(2). The different parts of the pad - system.

A number of tests were conducted on water flow rates on vertical aspen pads of different thicknesses, Watt (1963). Optimum cooling efficiency was achieved with an air - water flow ratio of about $40 \mathrm{~kg}$ of air for each kilogram of water. At the optimum air - water ratio, in Watt's test, an average of 7.5 liter of water was pumped for each liter evaporated, or about $2.4 \mathrm{~L} /\left(\mathrm{min}-\mathrm{m}^{2}\right)$ of pad surfaces. A general recommendation to 
accommodate typical pad heights of 1 to $2 \mathrm{~m}$ was the use of $6 \mathrm{~L} / \mathrm{min}$ per linear meter of pad, Welchert and Wiersma (1972). This was in a close agreement with the recommendation of Watt (1963).

Sizing the evaporative pad, based on the previous discussion, was determined using the maximum air flow rate and pad face velocity. The maximum ventilation rate of the controlled room, obtained from the output results of the computer simulation, was $1.27\left(\mathrm{~m}^{3} / \mathrm{s}\right)$. Consequently, the actual ventilation rate required was $1.8\left(\mathrm{~m}^{3} / \mathrm{s}\right)$ assuming 0.7 cooling system efficiency, Hellickson and Walker (1983). Accordingly, the pad surface area required was calculated as $1.44 \mathrm{~m}^{2}$ using $1.25(\mathrm{~m} / \mathrm{s})$ pad face air velocity.

The sump size is somewhat dependent on pump configuration, type of pad, and bleed-off rate. General recommendation about minimum sump capacities per unit pad area and minimum water rate per linear length of pad are available in the literature. A $30\left(\mathrm{~L} / \mathrm{m}^{2}\right)$ sump capacity of pad area was recommended for the use of (2-6) L/(min.m), minimum water rate per linear length of pad, (Hellickson and Walker, 1983).

In order to design the evaporative cooling system, the maximum air ventilation rate inside the broiler room, number of fans, pad face area, water flow rate, water pump capacity, sump and water tank size were determined. The computation procedure was carried out as follows:

1- The maximum ventilation rate required for the broiler room to raise 345 bird achieved from the computer simulation out put was 1.27 $\mathrm{m}^{3} / \mathrm{sec}$.

2- Assume the efficiency of the cooling system is $70 \%$, (Helliekson and Walker,1983), therefore, The ventilation rate $\mathrm{G}=1.27 / 0.7=1.8$ $\mathrm{m}^{3} / \mathrm{sec}$.

3- Assume pad face air velocity, $\mathrm{V}=1.25(\mathrm{~m} / \mathrm{s})$, (Hellickson and Walker,1983), then the pad surface area, $\mathrm{m}^{2}$ was :

$$
\mathrm{A}=\mathrm{G} / \mathrm{V}=1.8 / 1.25=1.44 \mathrm{~m}^{2}
$$

4- The pad surface area was presumably divided into two parts for practical consideration, each part $1 \mathrm{~m}$ width, $0.72 \mathrm{~m}$ high and $12 \mathrm{~cm}$ thick. 
5- The total number of fans was determined by dividing the total ventilation rate

over the fan capacity.

6- According to the fan specification available on the local market, the fans size $50 \times 50$ with $40 \mathrm{~cm}$ diameter was the more appropriate size to fit for the broiler room. Therefore,

The number of fans $=\frac{\text { Ventilation rate }}{\text { rate delivered by one fan }}=\frac{1.8\left(\mathrm{~m}^{3} / \mathrm{s}\right)}{1.194\left(\mathrm{~m}^{3} / \mathrm{s} . \text { fan }\right)}=1.5 \approx 2$ fans

Thus, two fans each having a capacity of $1.2 \mathrm{~m}^{3} / \mathrm{s}$ were considered sufficient to be used with the evaporative cooling system.

7- Water flow rate was calculated using the minimum recommended rate $(2 \mathrm{~L} / \mathrm{min} / \mathrm{m})$ as follows: $\mathrm{W}=$ length of $\mathrm{pad} \times 2(\mathrm{~L} / \mathrm{min} / \mathrm{m})=2(\mathrm{~m}) \times$ $2(\mathrm{~L} / \mathrm{min} . \mathrm{m})=4 \mathrm{~L} / \mathrm{min}$

8 - Water pump capacity $=$ length of pad $\times 7.4(\mathrm{~L} / \mathrm{min} . \mathrm{m})=2 \times 7.4=14.8$ $\mathrm{L} / \mathrm{min}$

9- Sump size $=$ pad face area $\times 3\left(\mathrm{~L} / \mathrm{m}^{2}\right)=1.44\left(\mathrm{~m}^{2}\right) \times 3\left(\mathrm{~L} / \mathrm{m}^{2}\right)=4.32 \mathrm{~L}$ 10- Water tank size $=$ pad face area $\times 25\left(\mathrm{~L} / \mathrm{m}^{2}\right)=1.44 \times 25=36 \mathrm{~L}$

One room was equipped with the evaporative cooler and mechanical ventilation system, whilst the other room used natural ventilation. Two exhaust fans, $1.2\left(\mathrm{~m}^{3} / \mathrm{s}\right)$ at $2\left(\mathrm{~mm} \mathrm{H}_{2} \mathrm{O}\right)$ static pressure were used with the mechanical ventilation system.

The fans were set up in one side wall, while the evaporative cooler was installed on the opposite side wall.

\subsection{Instrumentation and measurements}

A scheduler devise was used to measure the air temperatures and relative humidities inside and outside the broiler house in the controlled and cool rooms on an hourly basis. The measurements were also carried out every four days throughout the growth out period.

Average values were also achieved for both air temperatures and relative humidities throughout each day. Air temperatures and relative humidities before and right after passing through the pad were also measured. Three readings for the air temperatures and relative humidities were carried out at three different positions behind the pad and the average of these readings was calculated. 
Air temperatures and relative humidities were also measured inside each room. The readings were taken one meter apart along the travel of air from the pad to the fan and also at bird level of $20 \mathrm{~cm}$ above the ground which was considered the most representative of the bird environment.

A hot wire Anemometer was also used to measure the air face velocity at the inside pad surface. Nine readings were taken and the average was calculated. The average of three readings was also taken to the air velocity passing across the fans to determine the air velocity at exist of the fan.

Birds were weighed starting from the age of 21 days using an electronic balance. This bird age was considered the beginning of the growth out period. The weights were taken once every 6 days until birds reached the market age, 45 days. The feeding rates during the experiments were also daily measured.

The feed conversion ratio (FCR) is the amount of feed consumed per unit body gain. It was used to measure the bird performance using the following equation:

$$
F C R=\frac{\text { Feed Consumption }}{\text { Body Gain }} \times 100
$$

The feed nutrients that can be used for growth and gaining weight are only the amounts left over after the bird's survival needs are met. Under conditions such as sever hot or cold, or even diseases, a broiler flock may divert feed entirely to maintenance and gain little or no weight during a 24-hour period. This was the reason of why optimum environment for birds must be met. Birds have to use the least amount of feed for maintenance, and can use the most feed nutrients for weight gain. Birds with the lowest maintenance requirements always shift the most nutrients into growth and accordingly are reflected in better overall performance. Lastly, the mortality ratio was calculated using the following equation:

$$
\text { mortality ratio, } \%=\frac{\text { Total number of dead birds }}{\text { Total Number of birds }} \times 100
$$




\subsection{Economic Traits}

In the economic traits, body weight was recorded and body weight gain was calculated for each chick in grams every four days. Feed consumption was also daily recorded by subtracting the residues from offered amount of feed for each group in a certain pen. The average of feed consumption for each chick (gram feed/chick/period) was calculated by dividing the total feed consumed of a certain group by the number of chicks of that group. Feed conversion (gram feed/gram meat) was estimated for each period per chick by dividing the average of feed consumption of a certain period on calculated body weight gain for that particular period. Mortality ratio was calculated for each period as the percentage of the number of dead birds to the initial number of chicks during a certain period.

\subsection{The statistical analysis}

A randomized complete block design RCBD was used as an experimental design for the trials. The ANOVA table for the RCBD experimental design is presented in Table (1).

Table (1). ANOVA table for RCBD experimental design

\begin{tabular}{llll}
\hline S.O.V & d.f & S.O.V & d.f \\
\hline Blocks (Blk) & 1 & Replicates & 2 \\
Treatments (Trts) & 2 & Error & 10 \\
Blk $*$ Trts & 2 & Total & 17 \\
\hline
\end{tabular}

\section{RESULTS AND DISCUSSION}

A mathematical computer program was developed to predict and describe the system performance of broilers and to determine the ventilation rates and cooling loads required during the summer months based on (ASAE, 1988, MWPS 1983 and Ibrahim,1993 and 1988). Three ventilation rates were achieved to control interior air temperature, humidity, and ammonia. A fan-pad system was designated afterwards based on the output results of the simulation model. The system was constructed thereafter and installed for field tests. It was installed in one chicken room, while another one was used as a control treatment using natural ventilation. A 
comparison between the two growth rooms was carried out in order to study the effect of controlling environment on bird performance. The comparison included the bird body gain, feed conversion ratio, and cumulative bird mortality rate. The evaporative cooler was successfully increased the profit and appeared economically feasible to use.

\section{Simulating the bird performance}

The computer program was developed to predict and describe the performance of birds on an hourly basis. Bird weight increased from roughly $0.05 \mathrm{~kg}$ at one day old until it reached about $1.5 \mathrm{~kg}$ at market age, 45 day.

The sensible, latent, and total heats produced by birds are illustrated in Figure (3). The latent heat was defined as the moisture rate produced by bird respiration. The sensible, latent, and total heats were directly proportional to the bird age. In more price words, they were directly proportional to the bird weight. The sensible and latent heat produced by birds must be removed outside the building. Otherwise, the inside air temperature and humidity will increase dramatically over the optimum environment recommended.

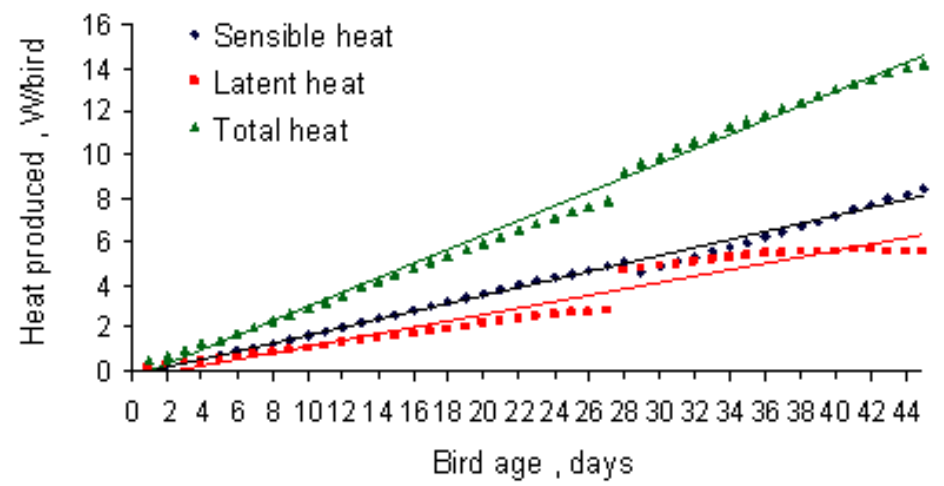

Fig. (3). The sensible, latent, and total heat produced via the life cycle.

The ventilation rates required for temperature, moisture, and ammonia control were plotted in Figure (4). The simulation of the broiler life cycle started on the $15^{\text {th }}$ of July and ended by the end of August. This was the period at which the air temperatures at summer reached their peak values. 
It was expected that the ventilation rate for temperature control was the greatest. This was because of the heat waves and high outside temperatures during that period. Moreover, ventilation rates required to control temperature, moisture or ammonia during almost the first ten days were negligible. The interior air temperature during this period was set at roughly $35^{\circ} \mathrm{C}$. In addition, no substantial ventilation rate was required to control either respired moisture produced by birds or ammonia release from the bird litter.

Ventilation rates for ammonia control were greater than those needed to control both air temperature and moisture at the begging of the life cycle. However, after almost 10 days of age, air temperature and moisture became the controlling factors for ventilation rates. The need for increasing the ventilation rates to control air temperature and moisture were due to the increase in bird sensible heat and moisture produced. Moisture sources were from both bird respiration and litter fecal. These were occurred as birds grew older.

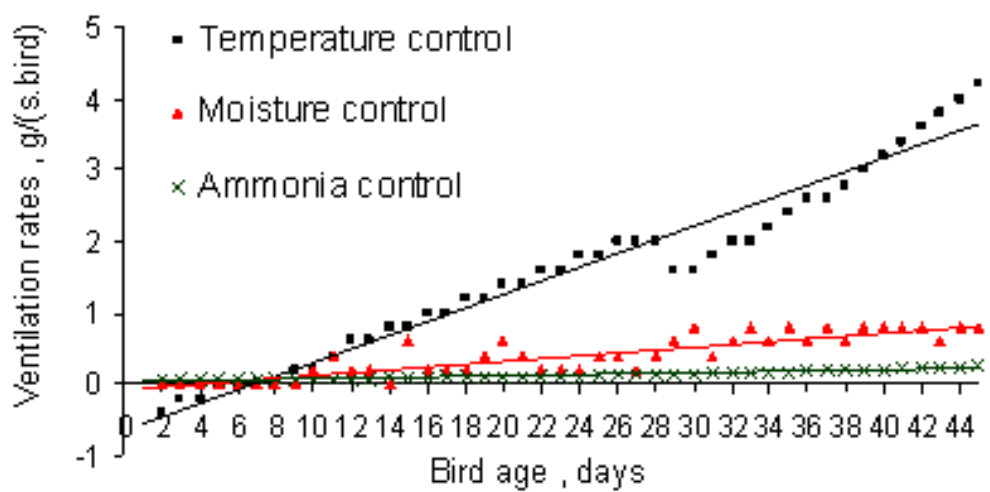

Fig. (4). Simulation of daily average ventilation rates.

A comparison between the predicted sensible heat produced by birds and heat losses components within the building is indicated in Figure (5). The average rate of increase of bird sensible heat produced was about 0.18 (W/bird) per day. This increase was linearly until reached its maximum value at market age, approximately 8 (W/bird). The increasing rate of heat loss from the bird litter by evaporation was around 0.077 (W/bird) per day. It was roughly represented $43 \%$ the rate of sensible heat produced. The increase of heat loss due to ventilation during the life 
cycle, corresponded with the increase of ventilation rate required as broilers get older. Heat loss by ventilation was also affected by the air temperature difference between inside and outside the broiler house. The predicted rate of heat transfer throughout the building walls, the ceiling, and the floor during the entire period of the life cycle trivially fluctuated with the outside air temperature. It was the smallest component in comparison to the other three heat loss components.

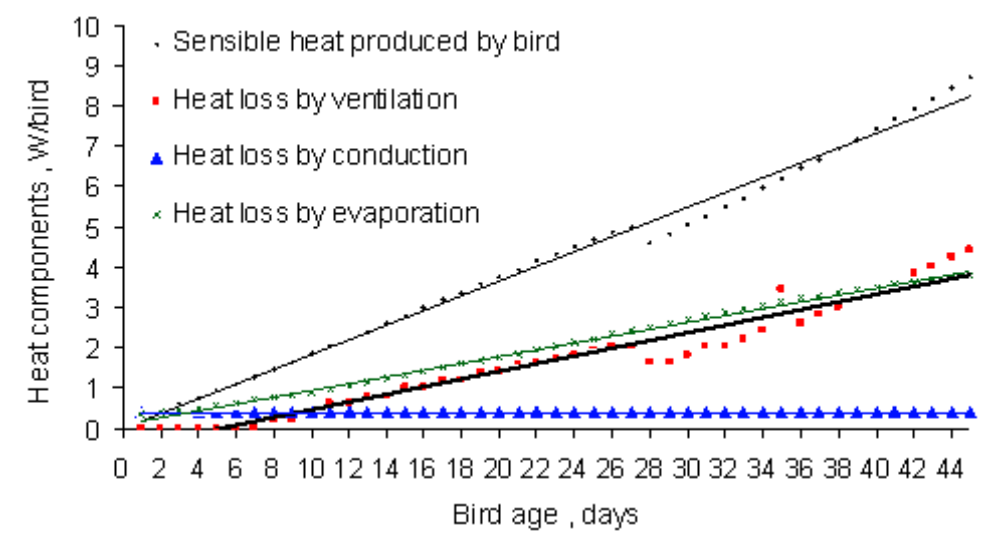

Fig. (5). Simulations of heat losses and gains inside the broiler house.

\section{The evaporative cooler testing}

Maximum ventilation rates to control temperature, humidity, and ammonia were $3.25,0.7$, and $0.2 \mathrm{~g} /$ (s.bird), respectively. The maximum predicted cooling load was $0.1 \mathrm{~W} / \mathrm{bird}$. In addition, the experimental results indicated that the evaporative cooler was capable to reduce the interior air temperature by roughly $5{ }^{\circ} \mathrm{C}$. The operating and system efficiencies of the evaporative cooler reached up to $35 \%$ and $90 \%$, respectively. The actual cooling load obtained by the evaporative cooler was almost 0.2 (W/bird).

The feed conversion ratios were also determined as 2.6 and $3.6 \mathrm{~kg}$ feed per $\mathrm{kg}$ meat for the cool and natural room, respectively. This was found at bird age 39 day. The cumulative bird mortality rates were also recorded. They reached at the market age 4 and $1 \%$ for the control and cool rooms, respectively.

A cost analysis proved that the profits were 2723 and 1820 EG.P./life cycle for the cool and control chamber, respectively. The profit of birds 
produced in the cool room was almost 1.45 times that of birds produced in the control room. Therefore, the evaporative cooler was successfully increased the profit and appeared economically feasible to use.

Based on simulation outputs results, the evaporative cooler was firstly sized. Three ventilation rates were computed to control air temperature, moisture and ammonia release. The maximum predicted ventilation rate was used in this analysis. The cooling system was installed in one growth room based on the maximum ventilation rate, while natural ventilation was applied to the other bird room. The effect of the evaporative cooler on the interior air temperature is shown in Figure (6). Data presented in this figure were for a selective day in August. The birds on that day were at 33 day old. As indicated in the figure, the outside air temperature increased at day time and reached its maximum value in the afternoon. It started to decrease afterwards. The averagely outside air temperature at daytime was $31.6^{\circ} \mathrm{C}$. The interior air temperature in the cool room was averagely $27.5^{\circ} \mathrm{C}$.

Meanwhile, the interior air temperature in the control room, the naturally ventilated room, was averagely about $32.5^{\circ} \mathrm{C}$. The increase of interior air temperature in the control room over even the ambient air temperature was due to the sensible heat produced by birds. This heat was added to the inside air and caused the increase of its temperature. The difference in interior air temperature between the cool and control rooms, about $5{ }^{\circ} \mathrm{C}$, was due to the effect of using the evaporative cooler.

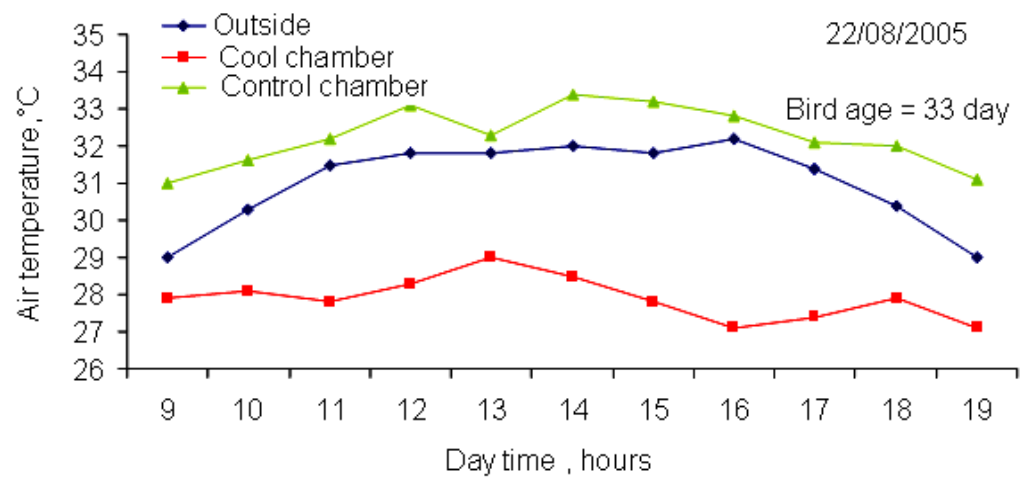

Fig. (6). The effect of using the evaporative cooler on interior air temperatures. 
Figure (7) illustrates the effect of using the evaporative cooler on the interior air temperatures for another day. Data presented in this figure were when bird age reached 45 day, the market age. The average air temperatures at daytime were $30.2,32.5$, and $28.2{ }^{\circ} \mathrm{C}$ for the outside and the interior air temperature in the control room, and inside air temperature in the cool room, respectively. Accordingly, the evaporative cooler was capable to reduce the interior air temperature by roughly, $4.2{ }^{\circ} \mathrm{C}$. Generally speaking, the cooling potential of the cooling system was averagely $4.6^{\circ} \mathrm{C}$. It was defined as the interior air temperature difference between the cool and control rooms.

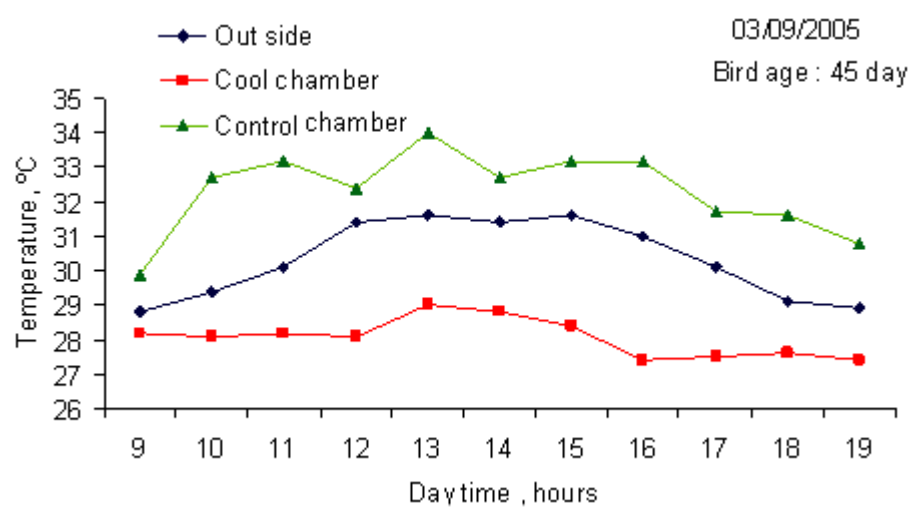

Fig. (7). The effect of using the evaporative cooler on interior air temperatures.

The cooling potential of the evaporative cooler was highly affected by the air humidity. The outside air relative humidity, inside air relative humidity in the cool room, and the inside air relative humidity in the control room are plotted in Figure (8). As revealed in the figure, the relative humidity of the outside air increased when it entered both rooms. Outside air carried moisture from both bird respiration and bird fecal litter when it entered the control room. Meanwhile, outside air carried moisture produced from the evaporative cooler, bird respiration, and bird litter when it entered the cool chamber. Consequently, the increasing rate of air relative humidity in the cool chamber, as expected, was greater than the rate of humidity increase in the control room. It was also worthy to not that the average outside air relative humidity was nearly $64 \%$. If the outside air relative humidity was less than this average, the cooling potential would be greater. 


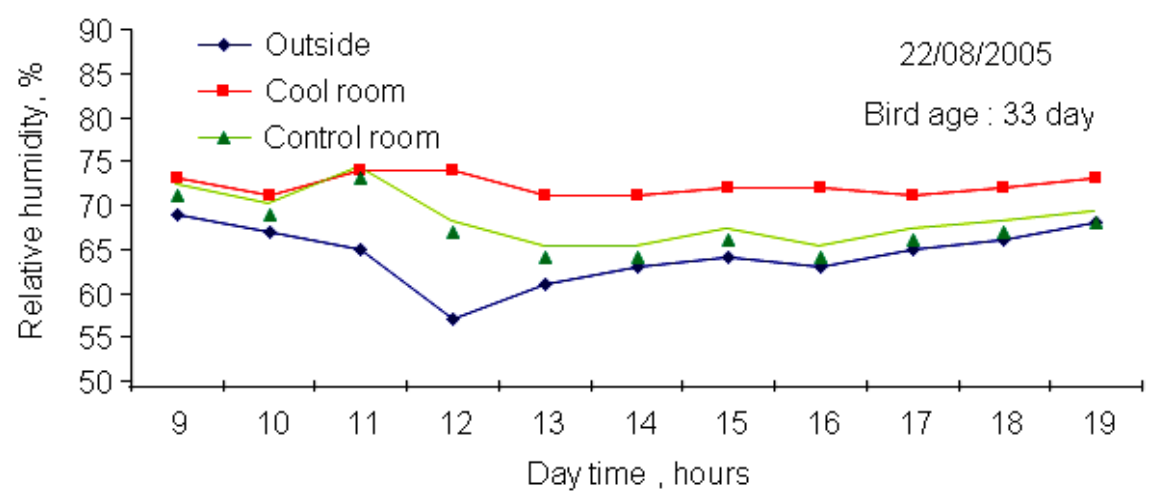

Fig. (8). The patterns of air relative humidities throughout day time.

The distribution of air relative humidities when bird reached 45 days old are also shown in Figure (9). Data were presented only at daytime since the evaporative cooler was presumably shut down at night. This was occurred since there was no need to run the system at night. The reason was because the outside air temperature actually dropped sharply at night and it became, when it entered the chicken room, within the thermal neutral zone of bird production. In addition, the system was shut down at night to save electrical energy consumption and hence reduced the operating costs.

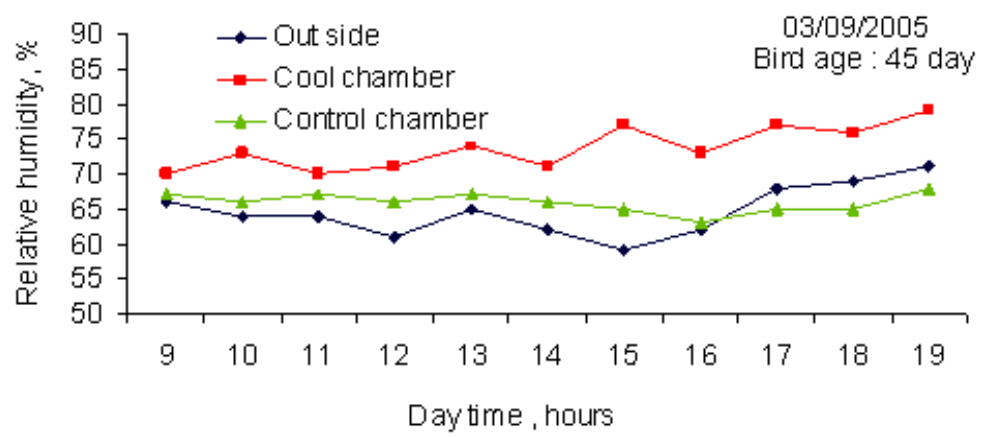

Fig. (9). The patterns of air relative humidities throughout day time.

The daily averages of outside and inside air temperatures in both rooms throughout the growth out period are indicated in Figure (10). The daily average applied to the particular day at which the point rests. As depicted from the Figure, the evaporative cooler provided staidly interior air room in the cool room. It kept the inside air temperature throughout the growth out period approximately around $28{ }^{\circ} \mathrm{C}$. Interior air temperature in the 
control room was, to certain extent, affected by the outside air temperature.

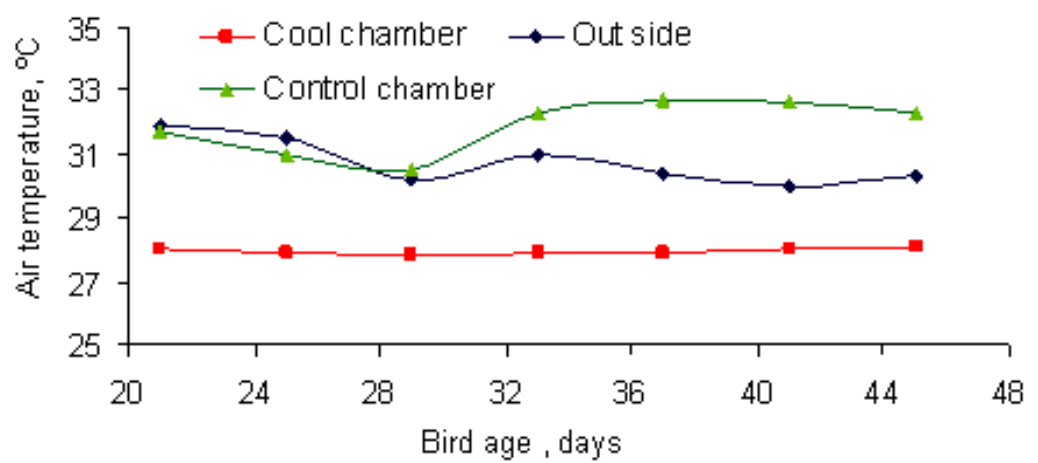

Fig. (10). The daily averages of air temperatures throughout growth period.

The daily average of interior air relative humidities for the growth out period are also declared in Figure (11). The interior air relative humidities in the cool room throughout the growth out period were roughly steady around $74 \%$. This meant that the evaporative cooler did not reach its maximum efficiency. It occurred since the interior air relative humidities throughout the growth out period did not reach the saturation situation, $100 \%$. Interior air relative humidities, as expected, were greater than those for outside air. The reason was evidently because the outside air carried moisture from both bird respiration and bird fecal litter when it entered the control room.

The system efficiency was defined as the temperature difference across the fan-pad system divided by the maximum allowable cooling potential. The latest was computed as the difference between the outside air temperature and its wet bulb temperature. There was a great difference between both efficiencies. It reached in some days almost the double. The very low operating efficiency, in comparison to the system efficiency, was certainly due to the high rates of bird respired moisture which added to the interior air. This was very clear at market age, 45 day, when the bird respired moisture reached its maximum value. The operating efficiency reached its minimum value, about $35 \%$, at that age. On the 
other hand, the system efficiency throughout the grow out period was averagely about $90 \%$. It was relatively considered high efficiency. It reflected the good prediction of sizing the cooling system.

The system and operating efficiencies throughout the daytime of a selective day where computed when bird reached the age of 25 day. The evaporative system efficiency was greater than the operating efficiency by about $20 \%$. In addition, the operating efficiency greatly fluctuated through the day. The difference between both efficiencies varied throughout the day from 7 to $32 \%$. This variation was due to the bird activity which affected both the bird respired moisture and moisture evaporated from the fecal litter. Outside relative humidity was almost steadily throughout this selective daytime.

The trend of both efficiencies, when bird reached 33 and 45 days, It was noticed that the minimum operating efficiency was always occurred at the beginning of the day. In addition, the maximum difference between the system and operating efficiencies happened also at the beginning of the daytime. The reason was more likely because of the so much built up moisture in the building during the previous night. Fans were quite often shut off at night to save energy and keep the building warm.

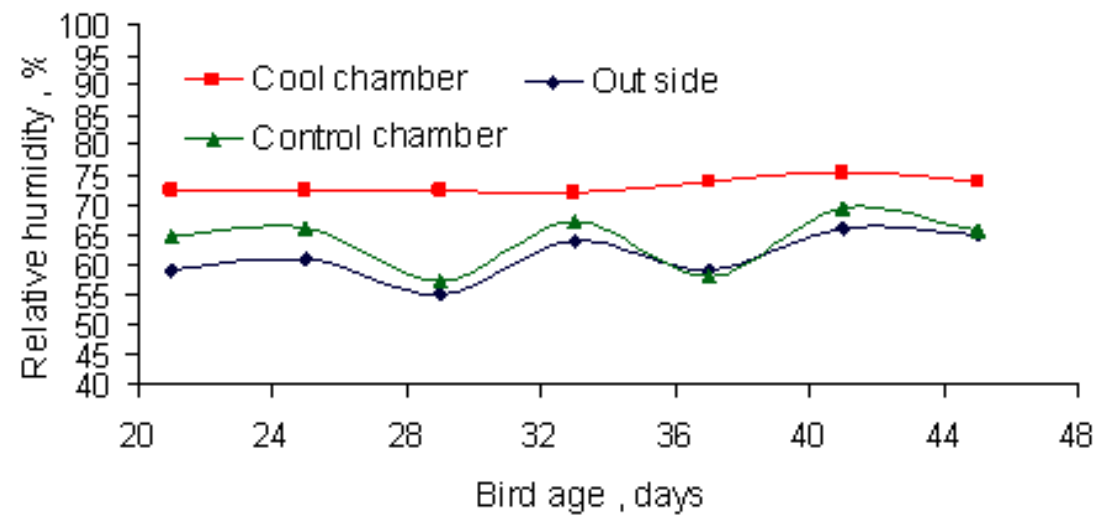

Fig. (11). The daily averages of air relative humidities throughout growth period. 
The predicted and actual cooling loads required in the bird room are plotted in Figure (12). The predicted cooling loads were achieved from the results of the simulation outputs. As revealed in the figure, the actual cooling loads during the grow out period were about 0.2 (W/bird). They increased slightly as birds grew. The sensible heat produced by birds dramatically increased throughout this period, whilst the designated interior air temperatures decreased. As revealed in the figure, the computer simulation program underestimated the results. In more precise words, the difference between the actual and predicted cooling loads was averagely 0.1 (W/bird). This was because of the assumptions made by the model. The fan-pad system, for instance, was new and its efficiency was greater than the value assumed in the simulation.

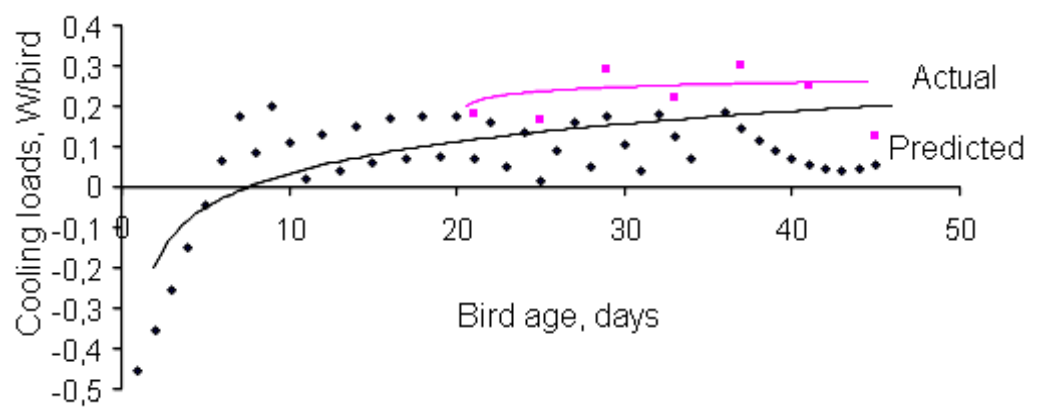

Fig. (12). Predicted and actual cooling loads during growth out period.

The effect of using the evaporative cooler on bird performance, particularly bird weights (BW), is shown in Figure (13). Data presented in this figure were collected at $10\left(\mathrm{bird} / \mathrm{m}^{2}\right)$ stocking density. Generally speaking, bird weights were linearly increased with bird ages. Deviations in bird weights, between the cool and natural ventilated rooms, were remarkable. At market age, the difference reached its maximum value, 0.4 (kg/bird). 


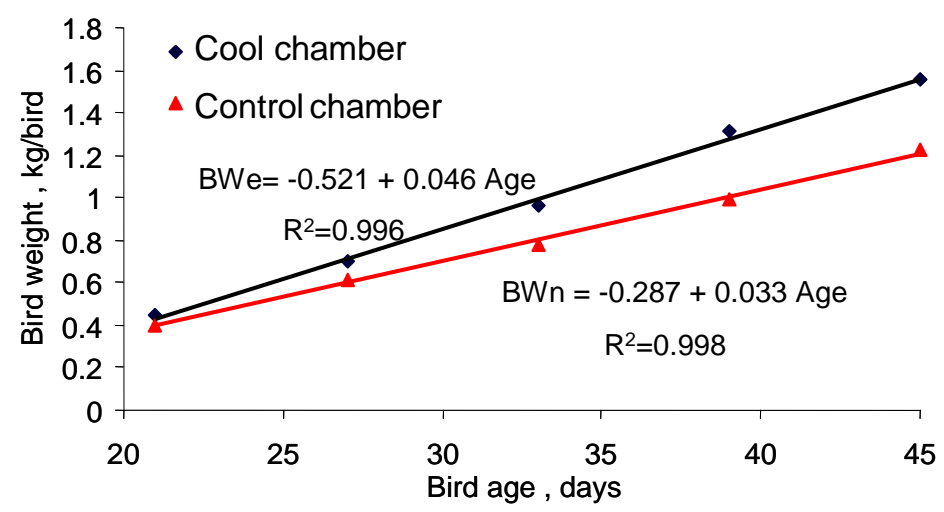

Fig. (13). Average bird weight throughout the growth out period.

The effect of using the evaporative cooling system on bird feed consumption is illustrated in Figure (14). The comparison was carried out using a stocking density $8\left(\mathrm{bird} / \mathrm{m}^{2}\right)$. Data presented in this curve were for the average of 345 birds per room. The feeding rates were 26.9 and 26.6 $\mathrm{kg} / \mathrm{set}$ for the cool and control rooms, respectively.

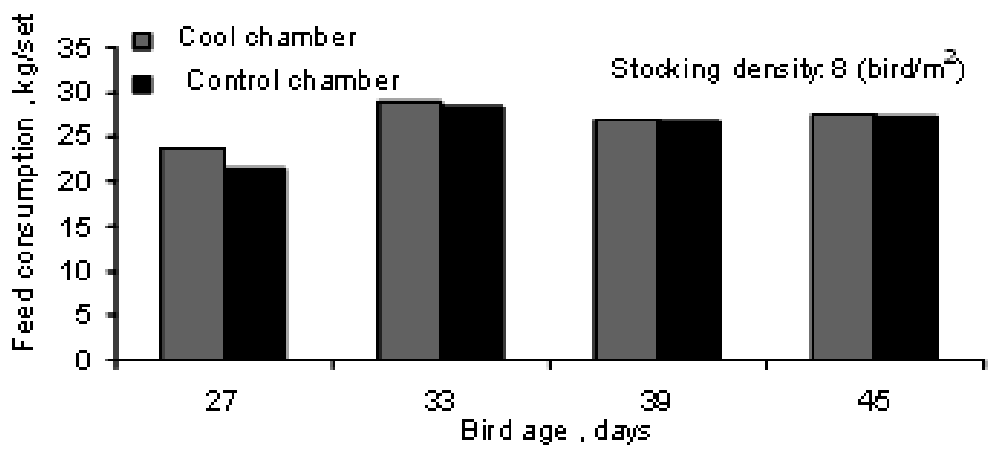

Fig. (14). The effect of using the evaporative cooling system on feeding rate

Figure (15) shows the effect of using the evaporative cooling on bird performance or the rate of body gain. Each point on the curve averagely represented the rate of body gain for 93 birds. Rates of bird body gains given in this figure were taken from birds raised at $8\left(\mathrm{bird} / \mathrm{m}^{2}\right)$ stocking density. The rate of body gain was defined as the increase of bird weight within a defined period, usually one week. For instance, the rate of bird body gain at age 33 day was the result of subtracting the bird weight at age 33 day from the bird weight at age 26 day. 
In addition, data for the rate of body gain presented at age 39 day represented the difference in body weight between birds at age 39 and 32 day and so on. Also there was a substantial effect of using the evaporative cooling on bird body gain. The differences between the two curves reached their maximum value at the beginning of the last week of production. The reason was more likely due to the increase of the sensible heat produced by birds. This heat was built up in the environment of the control chamber and caused heat stresses on birds. Meanwhile, the interior air temperature near the market age should be kept at its minimum level.

Therefore, weight gain didn't increase as expected because the birds stopped eating to focus attention on temperature control. On the other hand, the rate of bird body gain in the control room was almost steady through the grow out period.

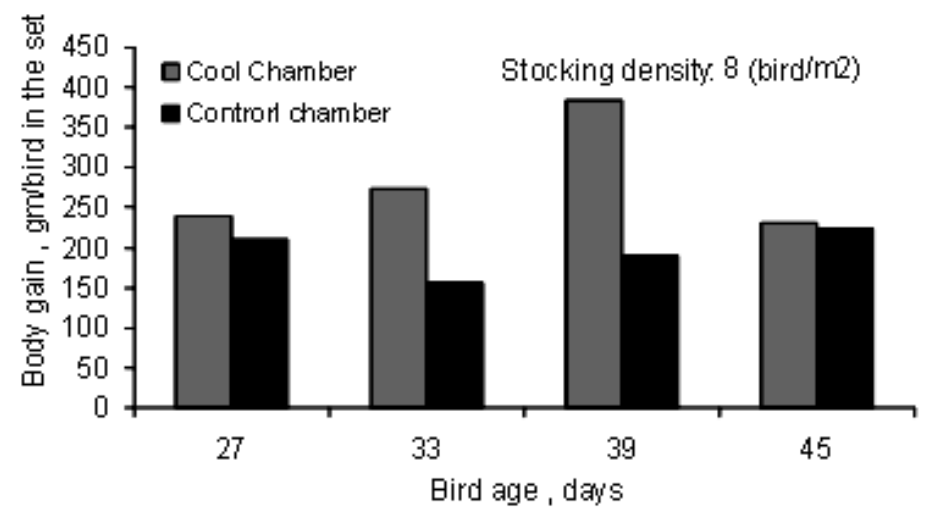

Fig. (15). The effect of using the evaporative cooling on the rate of bird body gain.

The cumulative bird mortality rates throughout the growth out period are plotted in Figure (16). It was expressed as the ratio of the sum of mortal or dead chicks divided over the whole chickens at age 21 day. Each pair of columns in the figure represented the cumulative mortality rate since the bird age 21 day until that particular bird age on which the column stands. The mortality rate was not computed from the bird age one day since the comparative study actually started at the beginning of the fourth week. Generally speaking, the cumulative mortality rates as expected increased with bird age. However, the difference in mortality rate between the two treatments increased substantially as birds grew. The 
cumulative mortality rates reached at the market age $4 \%$ and $1 \%$ for the control and cool rooms, respectively.

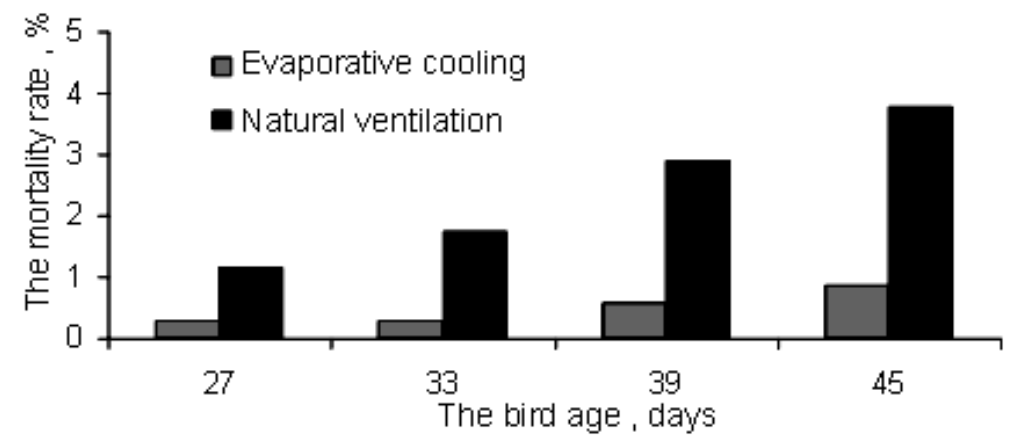

Fig. (16). The cumulative mortality rate throughout the growth out period.

\section{The Cost Analysis}

The ultimate goal of this cost analysis was to provide a decision making tool that can be used to decide whether or not the evaporative cooler was feasible to employ. The economic study quite often took into account the following procedure:

- The costs of bird production throughout the grow out period, EG.P./bird.

- The total income and the total costs (fixed and operating costs).

- The net profit which was computed by deducting the total costs from the total income.

The net profits of bird production in both rooms were determined. It was calculated from the total income after deducting the total cost. The total income was computed by multiplying the total kilograms of bird meat at market age times the current retail price per kilogram. The latest was assumed as $8 \mathrm{EG} . \mathrm{P} / \mathrm{kg}$. It was based upon the local market prices at the end of the experiments. The total weight of birds was estimated as the average bird weight at the market age times the final number of birds after subtracting the cumulative dead birds at the end of the experiment.

The total costs included both the fixed and operating costs. The fixed cost took into account the cost of construction, equipment, evaporative cooler, fans and motors. Meanwhile, the operating costs implied the costs of birds, feeding, medication, fan operating costs, bird litter, labor and transportation, and utilities. The fixed, operating, and total costs were 
calculated for both rooms. They were computed per year and the costs per life cycle were determined thereafter. Seven bird life cycles were assumed per year. The fixed, operating, total costs and the net profits for birds produced in both rooms were summarized and listed in Table (2). As can be seen from the table, the percent of increase of the net profit of birds produced in the cool room was almost $44.7 \%$ than the net profit of birds produced in the natural room. It was considered substantial. Accordingly, the evaporative cooler was successfully increased the profit and appeared economically feasible to use.

Table (2). Net profit for the controlled evaporative cooling and naturally ventilated rooms.

\begin{tabular}{lcc}
\hline \multicolumn{1}{c}{ Cost Analysis } & \multicolumn{2}{c}{ Room type } \\
\cline { 2 - 3 } & cool & natural \\
\hline Total cost, (EG.P./cycle) & 1381 & 1358 \\
Number of birds at market age & 342 & 331 \\
Final weight, (kg/bird) & 15 & 12 \\
Total income, (EG.P./cycle) & 4104 & 3178 \\
Profit, (EG.P./cycle) & 2723 & 1820 \\
Net profit, (EG.P./bird) & 796 & 55 \\
\hline$\%$ of Increase & \multicolumn{2}{c}{$44.7 *$} \\
$* \%$ of increase $=[(7.96-5.5) 100] / 5.5=44.7 \%$ \\
\end{tabular}

\section{CONCLUSIONS}

This research was carried out to investigate the feasibility of using an evaporative cooling system to improve the productivity of broilers. Two different treatments cool and control rooms, were used in the experiments. Mathematical computer program was first developed and the output results were used for designing the evaporative cooler. The system was manufactured and installed in the cool room thereafter for field tests. The maximum ventilation rates to control temperature, humidity and ammonia were $3.25,0.7$, and $0.2 \mathrm{~g} /($ s.bird), respectively. The evaporative cooler reduced the interior air temperature $5^{\circ} \mathrm{C}$. The operating evaporative cooling efficiency was $35 \%$, while the evaporative system efficiency reached up to $90 \%$. The actual cooling load obtained from the evaporative cooler was almost 0.2 (W/bird). The birds grow in the cool room were heavier than those raised in the control room by 0.3 ( $\mathrm{kg} / \mathrm{bird})$. 
The feed conversion ratios near the market age were 2.6 and $3.6 \mathrm{~kg}$ feed per kg meat for the cool and control rooms, respectively. No substantial differences were detected among the three stocking densities applied among the three stocking densities applied in the experiments for either body gain or feed consumption ratios. The cumulative bird mortality rates at the end of the experiments were $4 \%$ and $1 \%$ for the control and cool room s, respectively. The total costs of bird production were 1381 and 1358 (EG.P./life cycle) for the cool and control room s, respectively. The profits for the cool and control rooms reached up to 2723 and 1820 (EG.P./life cycle), respectively. The profit of the cool room was almost 1.45 times that gained from the control room.

\section{REFERENCES}

Abdel-Ghaffar, E. A.M. 1984. Ventilation curve of Commercial Poultry Buildings in Northwest Coast of Egypt During Winter. Agricultural Research Review, vol.62, No. 5A: $131-145$.

Abou Zaher, S. El-Sayed 1998. Environmental control systems of Agricultural structure (A Simulation Study on Broiler Housing System). Ph.D. Thesis. Department of Agricultural Mechanization, Tanta University.

ASAE standards. 1988. Design of ventilation systems for poultry and livestock shelters. American society of Agricultural Engineers standards. 270.5, pp $373-391$.

Deaton, J.W. ; Reece, F.N. AND McNaughton, J.L. 1978. The effect of temperature during the growing period on broiler performances. Poultry Sci, $57 ;$ 1070-1074.

FAO, 2002. Food and Agriculture Organization of the united Nations.

Harrison, P.C. and Biellier, H.V. 1969. Physiological response of domestic fowt to abrupt changes of ambient air temperature. Poultry Sci. $1034-1045$.

Hatem, M. H. 1987. Increasing Broiler Production in Egypt Through Environmental Control of the Existing Poultry Buildings. Misr. J. Agr. Eng. 4(4): 449 - 461. 
Hatem, M. H. 1988. Improving Broiler Houses Environment Under Saudi Arabian condition. Misr. j. Agr. Eng. 5(1): $32-44$.

Hellickson, M.A. and J.N. Walker. 1983. Ventilation of Agricultural Structures. An ASAE Monograph. ASAE. St. Joseph, MI.

Howes, J.R.; Grub, w. ; Roller, C.A. 1962. The effects of constant high temperatures regimes upon broiler growth, feed efficiency, body composition, and carcass quality. poultry Sci. 41 : 1652.

Ibrahim, M.H. 1988. Mathematical Simulations of Air - to - air Heat pump brooding for broilers. Unpublished Ph.D. Dissertation. Maryland University, U.S.A.

Ibrahim, M.H. 1990. Factors affecting energy demands for broiler production in Egypt. Misr. J. Agric. Eng., 7(2) : 173 - 182.

Ibrahim, M.H. 1993. A mist - fog system for poultry under hot - arid climates. Alex. J. of Agric. Eng. Vol (43) - No.2.

MWPS. 1983. Structures and environmental Handbook. $11^{\text {th }}$ Ed. Iowa State University, Ames. pp 633.4.

Watt, Jon. R. 1963. Evaporative air conditioning. The industrial press.

Welchert, W.T. and Frank Wiersma. 1872. Evaporative cooling for laying houses in Arizona ASAE PAPER 72 - 914.

Wiersma, F. and D.S. Benham. 1974. Design criteria for evaporative cooling. ASAE paper No. 74 - 4527, ASAE, St. Joseph, MI 49085.

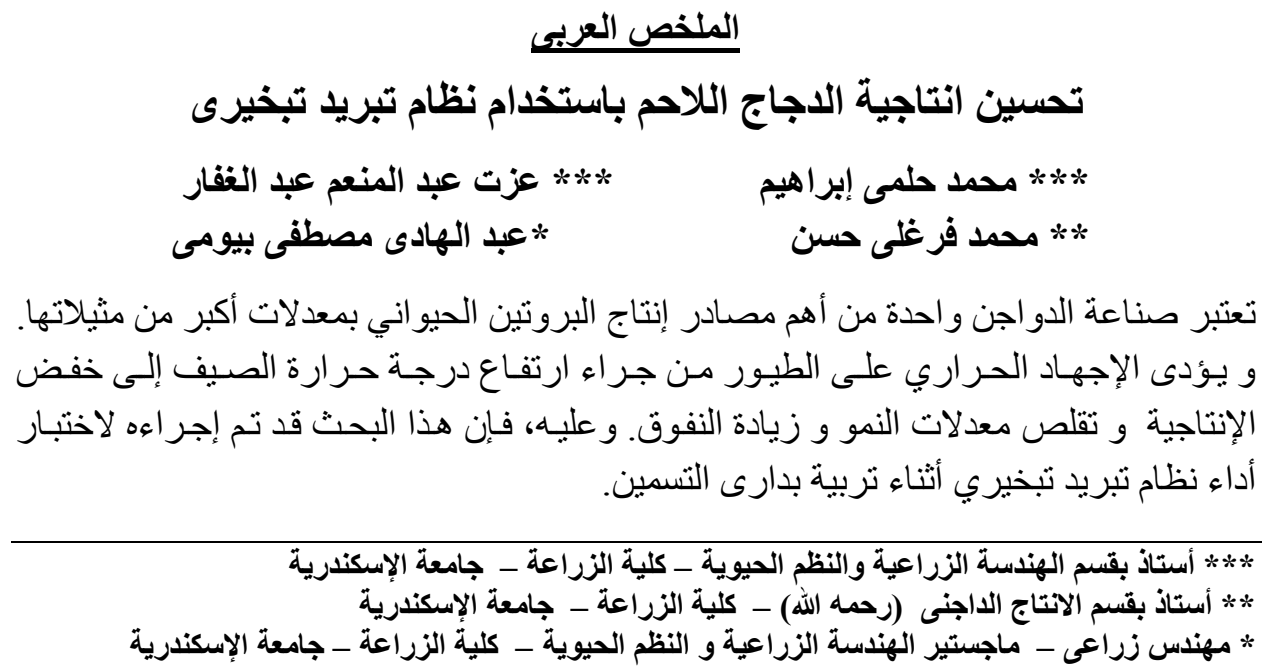




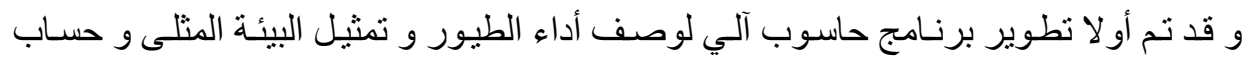

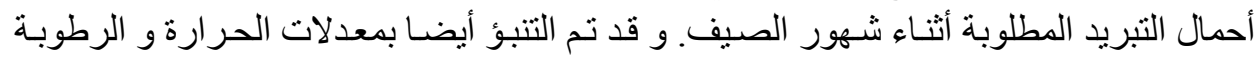

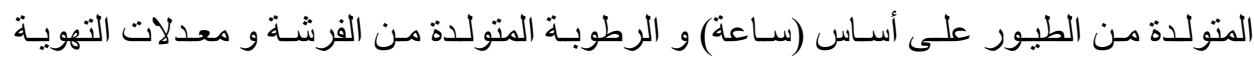

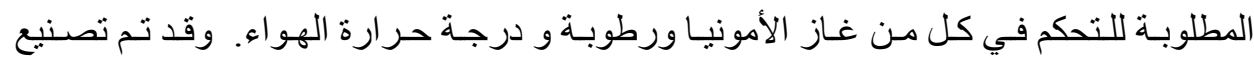

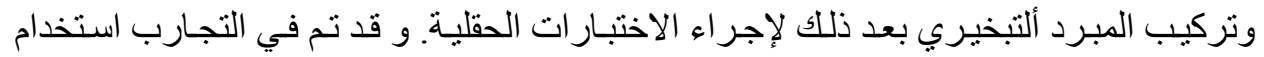

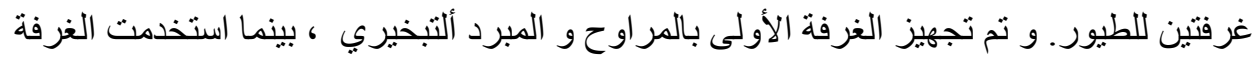

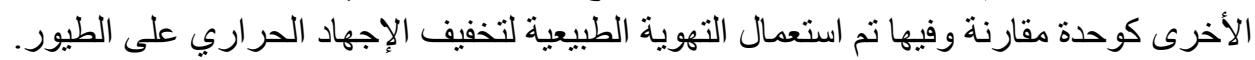
و قد أجريت المقارنات بعد ذلك بين الغرفتين بالنسبة لكل من أداء الطيور و معامل التحويل الغذائي ونسبة النفوق.

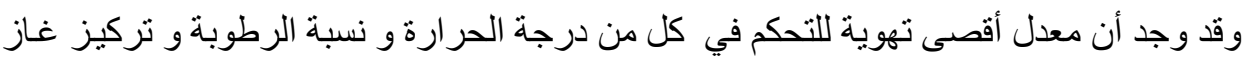

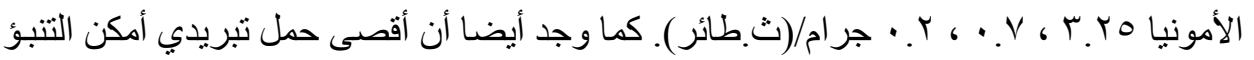

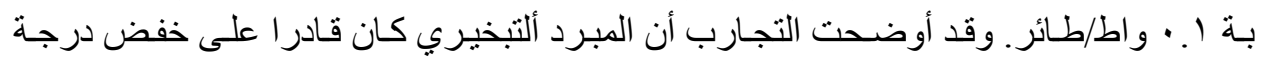

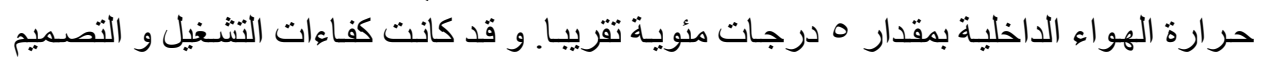

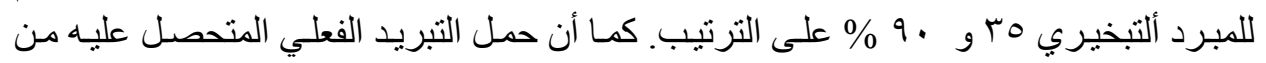

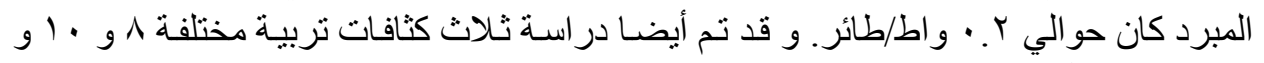

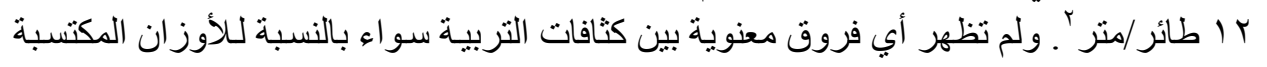

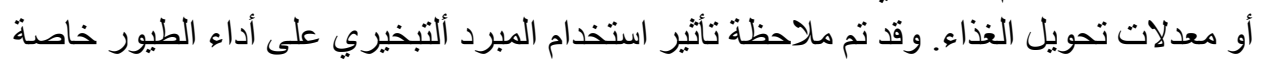

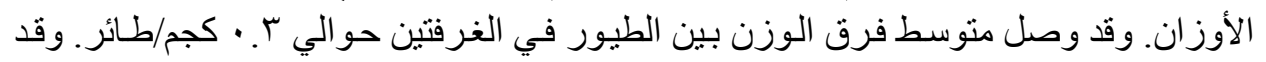

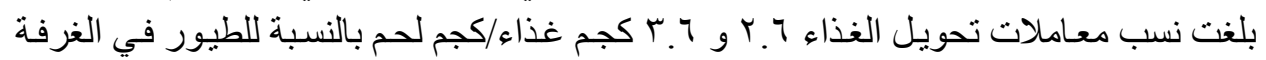

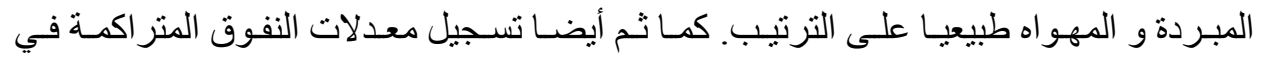
الغرفتين الطبيعية و المبردة على الترتيب.

و قد تم أجر اء تحليل اقتصادي بعد ذلك لمعرفة مـا إذا كان استخدام التبريد ألتبخيري ذو جدوى التح اقتصادية أم لا و وقد تضمن تحليل التكاليف كل من التكاليف الثابتة و المتغيرة و الكلية بالنسبة

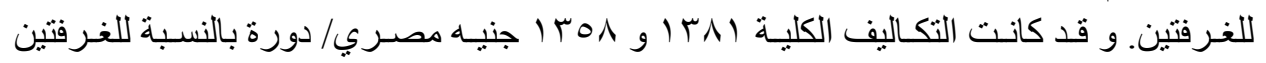

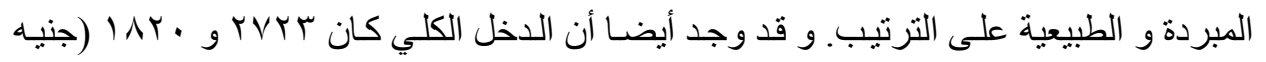

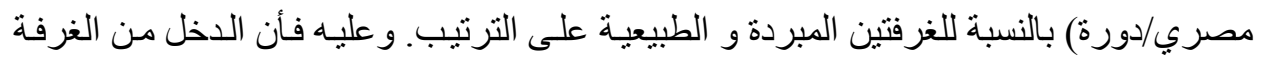

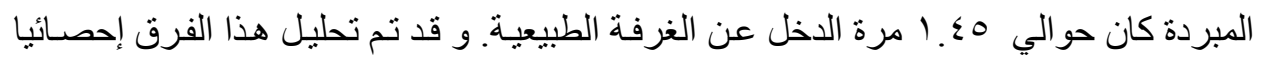
وكان معنويا عند درجة احتمال 0\%. و عليه، فقد برهن الته التجارب أن استخدام التبريد التبخيري في نربية دجاج اللحم ذو جدوى اقتصادية. 